\title{
CHRONOLOGY AND POSSIBLE LINKS BETWEEN CLIMATIC AND CULTURAL CHANGE DURING THE FIRST MILLENNIUM BC IN SOUTHERN SIBERIA AND CENTRAL ASIA
}

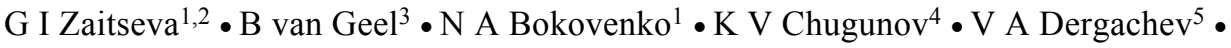 \\ V G Dirksen ${ }^{6} \bullet$ M A Koulkova ${ }^{1} \bullet$ A Nagler ${ }^{7} \bullet$ G Parzinger $^{6} \bullet$ J van der Plicht ${ }^{8} \bullet$ N D Bourova ${ }^{2} \bullet$ \\ L M Lebedeva ${ }^{1}$
}

\begin{abstract}
We reconstructed climate change during the second half of the Holocene for the Minusinsk (southern Siberia) and the Uyuk (Central Asia) valleys in the Eurasian steppe zone. Sediment cores from 2 lakes and a soil profile from the Arzhan-2 burial mount were investigated. We combined pollen and geochemical analyses and radiocarbon dating with the archaeological record. A sharp increase of human population density occurred at the transition from the Bronze Age to Iron Age (about 2700 cal BP). The most representative Scythian culture started in the Uyuk and the Minusinsk valleys after increased humidity and occupation capacity of the steppe zone during the 9th century BC.
\end{abstract}

\section{INTRODUCTION}

Long-term and short-term climatic variations during the Holocene have been recorded in highresolution studies of tree rings, ice cores, and peat deposits (cf. Dergachev et al. 2001; van Geel et al. 1996). Studies of cosmogenic isotopes, such as the radiocarbon content in tree rings and the ${ }^{10} \mathrm{Be}$ concentration in ice cores, show that cyclic climate variations with a duration of about 200 and $2300 \mathrm{yr}$ are caused by changes in solar activity (Vasiliev et al. 2002). At around 2700 cal BP (9th century BC), a sharp climatic shift was observed in different parts of Europe. This change had a global character and was associated with an abrupt decline of solar activity (van Geel et al. 1996, 1998; Speranza et al. 2002; Gracheva 2002). Some recently published studies evaluate possible evidence for climate change in the 1st millennium BC in Central Asia. Peck et al. (2002) studied the Holocene sediments of Lake Telmen in Mongolia and, based on the high-level terraces of the lake, concluded that an effective moisture balance greater than the present-day occurred between 2710 and $1260 \mathrm{cal}$ BP. Grunert et al. (2000) studied geomorphic changes in landforms and lake-level changes in the Uvs Nuur basin and adjacent areas in western Mongolia. The lakes Uvs Nuur and Bayan Nuur are situated just south of the Russian-Mongolian border and 100 to $200 \mathrm{~km}$ southwest of the Uyuk valley in Tuva. The reconstructed lake-level fluctuations indicate a decline in precipitation since about $5000 \mathrm{cal}$ BP. A sudden rise of lake levels, glacial advances, and soliflution started between 3000 and $2000 \mathrm{cal} \mathrm{BP}$, indicating enhanced rainfall and lower temperatures. Pollen analysis for a peat

\footnotetext{
${ }^{1}$ Institute for the History of Material Culture, Russian Academy of Sciences, St. Petersburg, Russia, Dvortsovaya nab. 18, 191186, St. Petersburg, Russia.

${ }^{2}$ Corresponding author. Email: ganna@mail.wplus.net.

${ }^{3}$ Institute for Biodiversity and Ecosystem Dynamics, Faculty of Science, University of Amsterdam, Kruislaan 318, 1098 SM Amsterdam, the Netherlands. Email: vangeel@science.uva.nl.

${ }^{4}$ State Hermitage Museum, Dvortsovaya nab. 36, 191186 St. Petersburg, Russia. Email: oaves@hermitage.ru.

${ }^{5}$ A.F. Ioffe Physical-Technical Institute, Russian Academy of Sciences, Polithechnicheskaya str. 26, 19402 St. Petersburg, Russia. Email: v.dergachev@pop.ioffe.rssi.ru.

${ }^{6}$ Institute of Volcanic Geology and Geochemistry, Russian Academy of Sciences, Piipa blvd. 9, 683006 Petropavlovsk-Kamchatsky, Russia. Email: dirksen@VD3155.spb.edu.

${ }^{7}$ Deutsches Archäologisches Institut, Eurasien-Abteilung, Podbielskiallee 69-71, 14195 Berlin, Germany.

Email: eurasien@dainst.de.

${ }^{8}$ Centre for Isotope Research, University of Groningen, Nijenborgh 4, 9747 AG Groningen, the Netherlands.

Email: plicht@phys.rug.nl.
}

(C) 2004 by the Arizona Board of Regents on behalf of the University of Arizona Proceedings of the 18th International Radiocarbon Conference, edited by N Beavan Athfield and R J Sparks RADIOCARBON, Vol 46, Nr 1, 2004, p 259-276 
deposit showed wetter climatic conditions since about $2500 \mathrm{cal}$ BP (Lehmkuhl et al. 1998), and that the vegetation around Bayan Nuur displayed a transition from steppe to a temporary forest phase.

The main focus in the present study has been on the Minusinsk and Uyuk valleys (Figure 1). These isolated mountain depressions in southern Siberia and Central Asia form part of the Eurasian steppe belt. These valleys are located in the central part of Eurasia, where the Altai-Sayan mountain ridges form a barrier for moist air masses from the Atlantic Ocean. Low and irregular precipitation, strongly depending on the topography, is the main factor controlling environmental changes and, possibly, the occupation history of the territory by ancient populations.

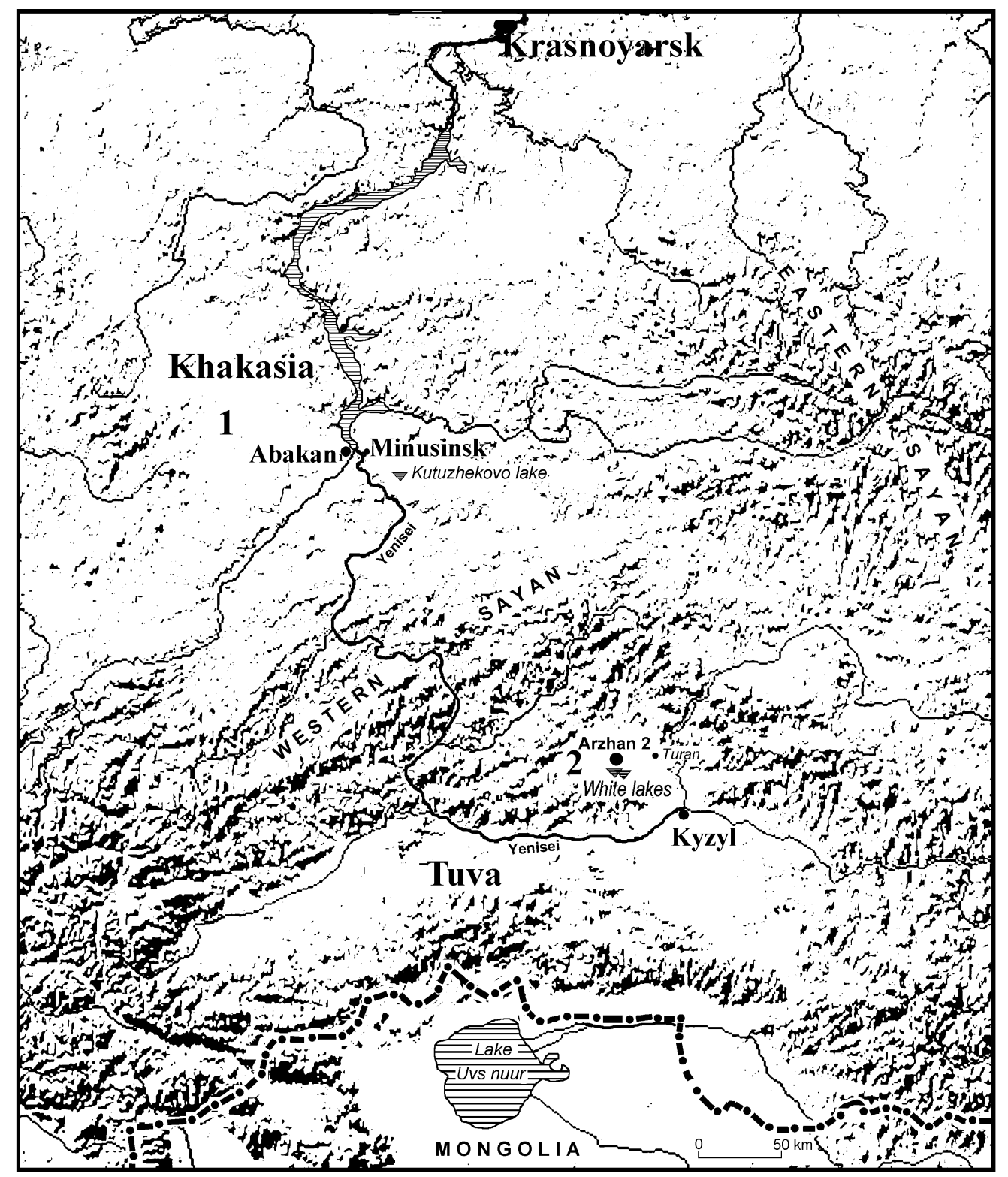

Figure 1 Map of the investigated region indicating the Minusinsk (1) and Uyuk valleys (2) 
The Minusinsk valley is located in the southern part of the Krasnoyarsk district and the Republic of Khakasia. The bottom of the valley, surrounded by the high mountain chains of the Sayans, is located at a height of 300-350 m. Sand dunes and some freshwater lakes are present in the central part of the valley; they probably originate from the ancient Yenisey River valley. The modern climate is continental with a mean annual temperature of about $0{ }^{\circ} \mathrm{C}$. The mean annual precipitation ranges from $250 \mathrm{~mm}$ in the western part of the valley (Khakasia) to $1500 \mathrm{~mm}$ in the eastern part, where the Western and Eastern Sayan Mountain ridges meet (Galvina 1954). A major part of the valleys was originally covered with bunchgrass steppe vegetation. Today, this area is mainly used for agriculture and settlements. Some patches of dense pine forests occur on the sand dunes. A piedmont of mountain ridges lies within the forest-steppe zone, while mountain taiga (coniferous and mixed forests) rises to a height of $1300-1800 \mathrm{~m}$.

The Uyuk valley is the section of the Turan-Uyuk mountain depression located in the northern part of the Tuva Republic. In the west and east, this valley is surrounded by the Sayan Mountain chains; in the south, it is bordered by the Uyuk Mountain ridge. The bottom of the valley is located at $650-850 \mathrm{~m}$. The present climate is extremely continental with a mean annual temperature below $0{ }^{\circ} \mathrm{C}$. The mean annual precipitation is about $300 \mathrm{~mm}$ and most of the rainfall occurs during the summer (Efimtsev 1957). The main vegetation types of the valley are steppe and saline meadows, while the mountain slopes are covered by forest.

These regions have long been investigated by archaeologists, and links between cultural and environmental changes may exist.

The St. Petersburg Radiocarbon Laboratory Database produced about $300{ }^{14} \mathrm{C}$ measurements for 80 sites located in Khakasia, and $140{ }^{14} \mathrm{C}$ measurements for 25 sites located in Tuva. Not all known sites have been ${ }^{14} \mathrm{C}$ dated, but a representative picture is obtained. The frequency of Holocene ${ }^{14} \mathrm{C}$ dates for the archaeological sites in the territory of the Eurasian steppe between $42^{\circ}$ and $55^{\circ} \mathrm{N}$ are shown in Figure 2 (curve 1), and for southern Siberia (Khakasia) combined with those from Central Asia (Tuva) (curve 2).

During the period between 8000 and 4000 BC, Mesolithic and Neolithic cultures were present all over the Eurasian territory, with the exception of southern Siberia and the Central Asian part of Russia (southern part of Krasnoyarsk district, Khakasia and Tuva). Occupation of these regions began during the Bronze Age and became more intense during the Iron Age. Figure 2 shows that both regions were essentially uninhabited during the Mesolithic-Neolithic periods up to 4500-4000 BP. Figure 2 also shows a sharp increase of archaeological sites after 3000 BP. The increase in settlements may be connected with the changed environmental conditions that influenced the economy of the ancient populations. Thus, we conducted our investigations to better understand the character of climatic changes and their possible influence on the development of archaeological cultures.

\section{METHODS}

We used pollen analysis and geochemical methods for the study of the lake deposits, supplemented by archaeological information and ${ }^{14} \mathrm{C}$ data. Most archaeological sites in the study area were ${ }^{14} \mathrm{C}$ dated (see Figure 2 for their distribution).

The lakes investigated were Kutuzhekovo (KTH; $\left.53^{\circ} 36^{\prime} \mathrm{N}, 91^{\circ} 56^{\prime} \mathrm{E}\right)$ Lake in the Minusinsk valley, and the 2 White Lakes (WL-1; 52 $05^{\prime} 11^{\prime \prime} \mathrm{N} ; 93^{\circ} 42^{\prime} 18^{\prime \prime} \mathrm{E}$ and WL-2; 52 $03^{\prime} 59^{\prime \prime} \mathrm{N} ; 93^{\circ} 43^{\prime} 40^{\prime \prime} \mathrm{E}$ ) in the Uyuk valley. During 2001 and 2002, we collected lacustrine sediment cores along the borders of these lakes using a Dakhnovsky sampler (Faergi and Iversen 1989) for sand deposits and a Russian 


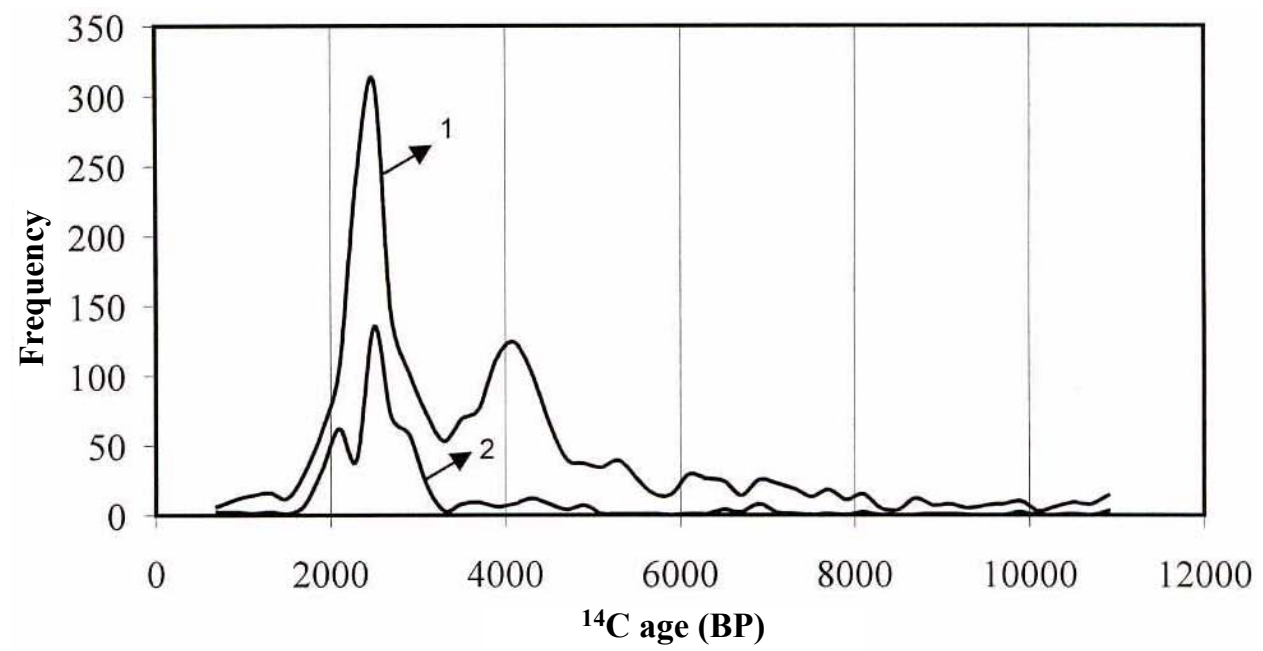

Figure 2 Distribution of ${ }^{14} \mathrm{C}$ dates of monuments located in the Eurasian steppe belt: 1) all of the Eurasian steppe; 2) southern Siberia (Khakasia) and Central Asia (Tuva).

sampler for the soft gyttja deposits. Subsamples from the longest cores were used for pollen and geochemical analyses.

The pollen samples were prepared at the University of Amsterdam using standard procedures (Faegri and Iversen 1989). An average of 507, 384, and 448 pollen grains were counted in samples from the WL-2 and KTH cores and from the Arzhan-2 site, respectively. Pollen percentages were calculated based on the total pollen sum, excluding spores and aquatic taxa. The WL-2 samples yielded scarce pollen and were omitted from the calculation. The percentages of other microfossils were also calculated based on the total pollen sum. The results are shown as percentage diagrams of the selected taxa. The pollen concentrations of the major components are also given in the diagrams, with the exception of the diagram for Arzhan-2, where the absolute pollen concentration was not calculated.

The samples for the geochemical analysis were collected together with the samples for pollen analysis. The aeolian-soil deposits were sampled from the open cross-section buried under the Arzhan-2 monument. The samples for geochemical analysis were taken from each layer of the stratigraphical successions.

Standard analytical techniques were used to measure the chemical composition of the samples (Soltanpour et al. 1996). We determined the elements $\mathrm{Na}, \mathrm{Ca}, \mathrm{Mg}, \mathrm{Al}, \mathrm{Fe}, \mathrm{Mn}, \mathrm{P}, \mathrm{Ti}, \mathrm{Zn}, \mathrm{Cu}, \mathrm{Ni}, \mathrm{Cr}$, $\mathrm{Ba}, \mathrm{Sr}, \mathrm{S}$, and $\mathrm{N}$, as well as the $\mathrm{CO}_{2}$ and $\mathrm{C}_{\text {org }}$ yield.

The correlation between the elements allows us to determine the mineral complexes of the samples. Sedimentological parameters were applied as paleoclimatic markers. The decay of vegetation during colder periods increases the $\mathrm{CO}_{2}$ concentration in the deposits. Such processes destroy the carbonate minerals (Eusterhaues et al. 2002). Precipitation with evaporation also results in the destruction of carbonate minerals. Dry environments favor carbonate precipitation (Hassan 1985). The $\mathrm{Ba} / \mathrm{Sr}$ ratio is used as a marker of relative temperature, following Chen et al. (1999) and Goldberg et al. (2000). We used the Chemical Index Alteration (CIA) to estimate the relative temperature. This indicator determines the weathering grade during increasing temperature and humidity (Bor-ming et al. 2001). An increasing CIA index in soil profiles is an indication of warmer climate. 
The ${ }^{14} \mathrm{C}$ dates were produced by 2 laboratories: ${ }^{14} \mathrm{C}$ laboratory of the Institute for the History of Material Culture (Zaitseva et al. 1999) and the Centre for Isotope Research, University of Groningen (van der Plicht et al. 1995; van der Plicht and Wijma 2000). The Institute for Material Culture (Le) employs the liquid scintillation technique and the Groningen laboratory (GrA) uses accelerator mass spectrometry (AMS). The counting form for measuring the ${ }^{14} \mathrm{C}$ concentration is benzene for the traditional methods, and graphite for AMS methods.

Chemical pretreatments to isolate the organic fractions from the lake soil deposits are similar for both dating techniques and consist of standardized washes with acid-alkali solutions (Arslanov 1986; Chichagov 1985). First, to eliminate exogenous carbonate, the soil samples were heated in $3 \%$ $\mathrm{HCl}$ solution for $30 \mathrm{~min}$ and then washed to neutral. The residue is then treated with cold $2 \% \mathrm{NaOH}$ solution for $20 \mathrm{hr}$. The alkali solution and residue are filtered, and from the alkali solution, the humic acids are precipitated by $\mathrm{HCl}$, then isolated by centrifugation. This humic acid fraction obtained is here named "cold humic." The residue filtered from the acid/alkali wash is boiled in $2 \% \mathrm{NaOH}$ solution for $4 \mathrm{hr}$, and after cooling, the humic acids are precipitated by $\mathrm{HCl}$ and separated by centrifugation. After washing to neutral and drying, this fraction of humic acids is here named "hot humic." Meanwhile, the charcoal was chemically pretreated with a standard acid-alkali-acid solution $(2 \%$ $\mathrm{HCl}$ and $2 \% \mathrm{NaOH})$.

The chemically treated humic acids and charcoal were then prepared for either liquid scintillation (Zaitseva et al. 1999) or AMS analysis (van der Plicht et al. 1995; van der Plicht and Wijma 2000) according to each laboratory's standardized procedures for ${ }^{14} \mathrm{C}$ dating.

Our choice of ${ }^{14} \mathrm{C}$ analysis type for certain samples was limited by the recovered sample size. Sample size limits on the amount of charcoal for liquid scintillation are between $0.8 \mathrm{~g}$ and $1 \mathrm{~g}$. For the humic samples, if the separate fractions of the humic acids (cold and hot) were not sufficient for dating, we chose to combine both fractions, and the ${ }^{14} \mathrm{C}$ date was produced from the total humic acids fraction ("Total humic acids," Tables 1, 2, 3).

\section{RESULTS}

\section{The Minusinsk Valley}

Organic layers from the sediment core collected from Kutuzhekovo Lake were ${ }^{14} \mathrm{C}$ dated in St. Petersburg (Le, conventional) and Groningen (GrA, AMS). We note that these deposits contain a low amount of organic material, particularly in the deepest part. The results are shown in Table 1.

The Kutuzhekovo (KTH) pollen record is constructed from 53 samples, including a surface sample from the lacustrine mud, and shown in Figure 3. Three main zones are distinguished in the pollen diagram:

- Zone KTH-I (235-165 cm; $4310 \pm 120$ BP [Le-6233], upper half of the zone) is characterized by domination of shrub pollen and by the highest values of xerophitic taxa. In the middle of the zone, the Betula sect. Nanae/Fruticosae pollen reach their maximum value (up to 48\%) and a sudden rise of pine pollen frequency occurs, while Artemisia and Chenopodiaceae show their peaks at the lower and upper parts of the zone. These xerophytic components taken together prevail over Cyperaceae and Poaceae and indicate dry conditions during this time interval, when steppe and desert-steppe persisted in the valley. All these features are indications of an arid period interrupted by a minor amelioration just before $4300 \mathrm{BP}$. The upper dry interval was obviously less arid than the lower one because of the higher Artemisia/Chenopodiaceae ratio (van Campo and Gasse 1993). The extremely low values of tree pollen $(<10 \%)$ found at the 
Table 1 Results of ${ }^{14} \mathrm{C}$ dating of deposits from Kutuzhekovo Lake.

\begin{tabular}{|c|c|c|c|c|c|c|}
\hline \multirow[b]{2}{*}{$\mathrm{Nr}$} & \multirow[b]{2}{*}{ Lab nr } & \multirow{2}{*}{$\begin{array}{l}\text { Depth } \\
(\mathrm{cm})\end{array}$} & \multirow[b]{2}{*}{ Material } & \multirow{2}{*}{$\begin{array}{l}{ }^{14} \mathrm{C} \text { age } \\
(\mathrm{BP})\end{array}$} & \multicolumn{2}{|c|}{ Calibrated dates, cal BC/AD } \\
\hline & & & & & $1 \sigma$ & $2 \sigma$ \\
\hline $\begin{array}{l}\text { KTH } \\
1\end{array}$ & Le-6234a & $106-120$ & $\begin{array}{l}\text { Hot } \\
\text { humic acids }\end{array}$ & $1530 \pm 90$ & $430-610 \mathrm{cal} A D$ & $330-670 \mathrm{cal}$ AD \\
\hline $\begin{array}{l}\text { KTH } \\
2\end{array}$ & Le-6234b & $106-120$ & $\begin{array}{l}\text { Total } \\
\text { humic acids }\end{array}$ & $1600 \pm 150$ & $320-610$ cal AD & 50-700 cal AD \\
\hline $\begin{array}{l}\text { KTH } \\
3\end{array}$ & Le-6231 & $146-158$ & $\begin{array}{l}\text { Total } \\
\text { humic acids }\end{array}$ & $2470 \pm 70$ & $770-510$ cal BC & $790-400$ cal BC \\
\hline $\begin{array}{l}\text { KTH } \\
4\end{array}$ & Le-6232 & $\begin{array}{l}158-176 \\
\text { (upper layer) }\end{array}$ & $\begin{array}{l}\text { Total } \\
\text { humic acids }\end{array}$ & $2630 \pm 180$ & $1000-520 \mathrm{cal} \mathrm{BC}$ & $1300-350 \mathrm{cal} \mathrm{BC}$ \\
\hline $\begin{array}{l}\text { KTH } \\
5\end{array}$ & GrA-20687 & $\begin{array}{l}158-176 \\
\text { (lower layer) }\end{array}$ & $\begin{array}{l}\text { Total } \\
\text { humic acids }\end{array}$ & $2985 \pm 45$ & $1320-1130 \mathrm{cal} \mathrm{BC}$ & $1390-1060$ cal BC \\
\hline $\begin{array}{l}\text { KTH } \\
6\end{array}$ & Le- 6233 & $176-195$ & $\begin{array}{l}\text { Total } \\
\text { humic acids }\end{array}$ & $4310 \pm 120$ & $3300-2650 \mathrm{cal} \mathrm{BC}$ & $3350-2600 \mathrm{cal} \mathrm{BC}$ \\
\hline $\begin{array}{l}\text { KTH } \\
1\end{array}$ & Le-6234a & $106-120$ & $\begin{array}{l}\text { Hot } \\
\text { humic acids }\end{array}$ & $1530 \pm 90$ & $430-610 \mathrm{cal}$ AD & $330-670 \mathrm{cal}$ AD \\
\hline
\end{tabular}

base of the core also indicate the maximum aridity of the record, with strongly reduced mountain forest.

- Zone KTH-II (165-117 cm; $2985 \pm 45$ BP [GrA-20687], beginning of the zone). This zone is characterized by abrupt starting pollen concentrations. The most significant features are the sharp rise of Cyperaceae, from $10 \%$ at the beginning of the interval up to $32 \%$ at the top, and a decrease of xerophitic taxa. This reflects a rapid vegetation shift due to an increase in moist conditions at about $3000 \mathrm{BP}$. The shrub birch percentages decrease quite rapidly to $5-10 \%$, and tree birch (Betula sect. Albae) appears. A gradual increase of Pinus sylvestris, which grows predominantly in the lower part of mountain forest and is adapted to grow on sand dunes in the valley, suggests a progressive forest shift down-slope as a response to increased moisture conditions. The KTH-II zone corresponds to a period with maximum humidity.

- Zone KTH-III (117-30 cm; $1600 \pm 150$ BP [Le-6234b] and $1530 \pm 90$ BP [Le-6234a], lower part of the zone). An increase in the frequency of highland pine species Pinus sibirica at the beginning of the zone indicates a warmer climate compared to the KTH-II interval. The values of xerophitic taxa are rather stable, while Poacea shows a sharp rise from $13 \%$ to $33 \%$ and reaches the highest values of the whole record. The change of domination from sedges to grasses reflects a drop in water level and a change in trophic conditions, stimulating the expansion of Phragmites vegetation around the lake. However, it is difficult to prove an exclusively local origin for grasses, because some Poaceae pollen grains could also originate from the surrounding steppe, rich in Stipa, Festuca, and Koeleria. In both cases, we can also deduce that the sudden change of Cyperaceae by Poaceae corresponds to the end of a period with maximum humidity.

The climatic changes as derived from the pollen data support our observations from our geochemical data.

For Kutuzhekovo Lake, the geochemical results are summarized as follows: 1) a detrital (alumosilicate) element group, consisting of $\mathrm{K}, \mathrm{Na}, \mathrm{Al}, \mathrm{Ti}, \mathrm{Ba}, \mathrm{Fe}$; (2) a carbonate group, consisting of $\mathrm{Ca}$, $\mathrm{Sr}$, $\mathrm{CO}_{2} ;(3)$ an organic group, consisting of $\mathrm{N}, \mathrm{C}_{\text {org }}, \mathrm{S}$. The analysis shows anti-correlation between alumosilicate elements and elements found in the organic material. The increase of detrital sediments in the lake deposits compared with organic material can take place in cool climatic conditions, or as the result of soil erosion. The amount of aluminum is the detrital (alumosilicate) index. The increase 


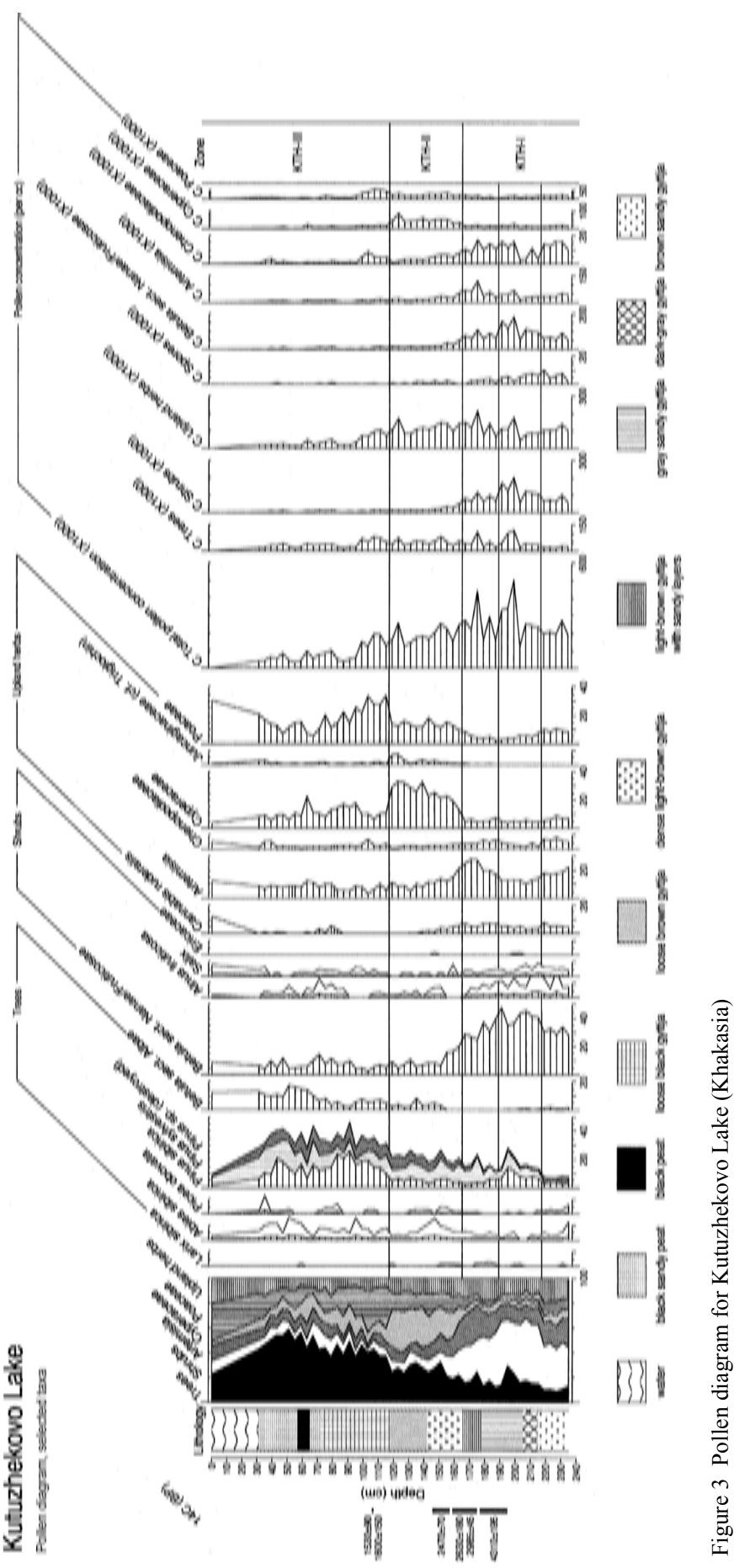




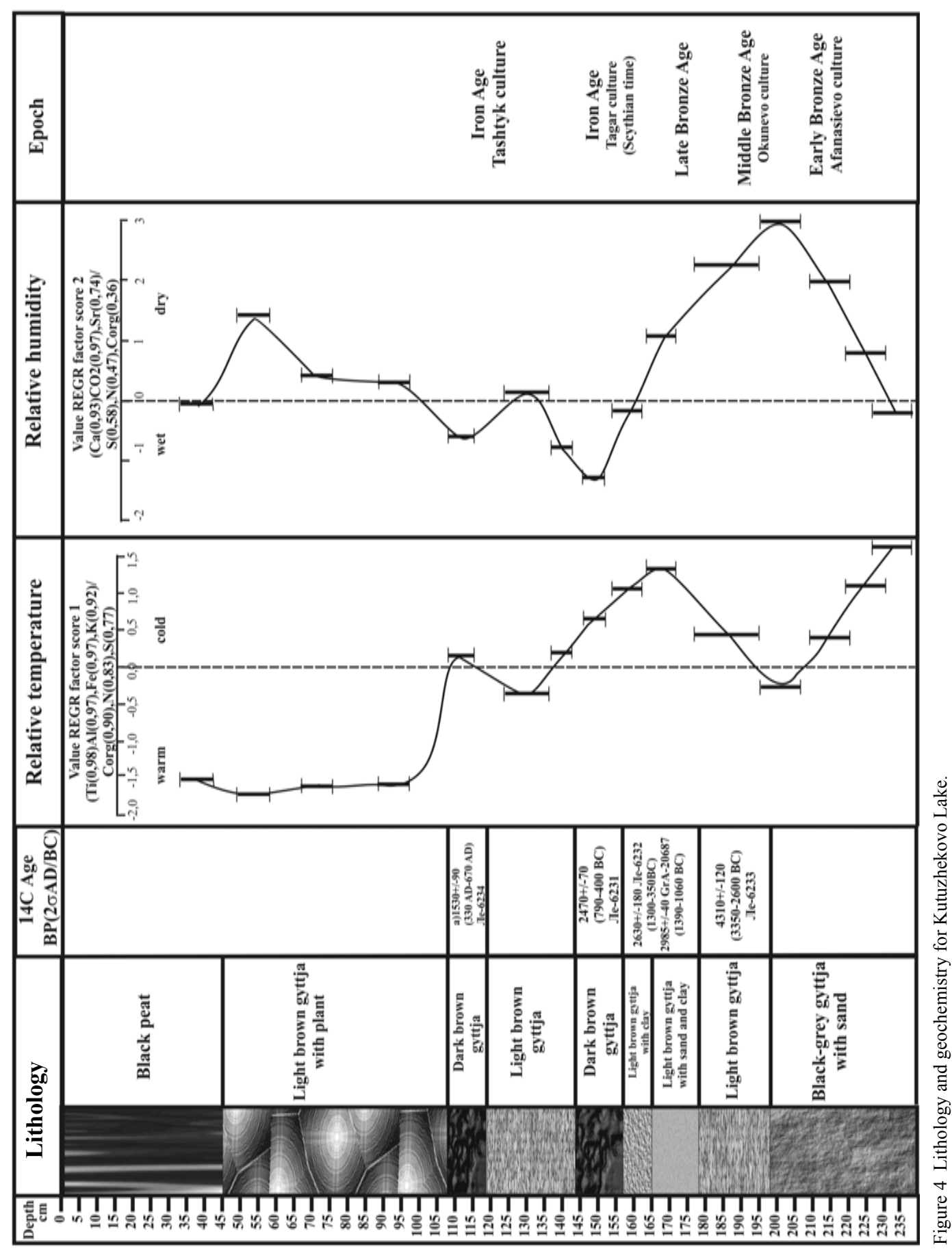


of clay-feldspar concentration in the lake deposits depends on the terrestrial sediment supply during the cold period (Eusterhaues et al. 2002). The analysis shows that temperature fluctuations can be determined this way, as well as relative humidity.

Figure 4 shows temperature and humidity changes, as derived from the geochemical data. A cool phase occurred during the 11th-8th centuries BC. An increase in humidity reached a maximum during the early Iron Age, when there was also a warming trend. In summary, the pollen record and the geochemical data both show a pronounced shift to humid climatic conditions at the start of the early Iron Age.

\section{The Uyuk Valley}

Results of the ${ }^{14} \mathrm{C}$ dating of the organic materials from the White Lake deposits are shown in Table 2.

Table 2 Results of ${ }^{14} \mathrm{C}$ dating of deposits from White Lake.

\begin{tabular}{|c|c|c|c|c|c|c|}
\hline \multirow[b]{2}{*}{$\mathrm{Nr}$} & \multirow{2}{*}{$\begin{array}{l}\text { Lab } \\
\mathrm{nr}\end{array}$} & \multirow[b]{2}{*}{ Material } & \multirow{2}{*}{$\begin{array}{l}\text { Depth } \\
(\mathrm{cm})\end{array}$} & \multirow{2}{*}{$\begin{array}{l}{ }^{14} \mathrm{C} \text { age } \\
\text { (BP) }\end{array}$} & \multicolumn{2}{|c|}{ Calibrated dates, cal BC/AD } \\
\hline & & & & & $1 \sigma$ & $2 \sigma$ \\
\hline $\begin{array}{l}\text { WL1 } \\
1\end{array}$ & Le-6195 & $\begin{array}{l}\text { Hot } \\
\text { humic acids }\end{array}$ & $20-40$ & $2090 \pm 100$ & $360 \mathrm{cal} \mathrm{BC}-20 \mathrm{cal}$ AD & $390 \mathrm{cal} \mathrm{BC}-80 \mathrm{cal} \mathrm{AD}$ \\
\hline $\begin{array}{l}\text { WL2 } \\
2\end{array}$ & Le-6499 & $\begin{array}{l}\text { Total } \\
\text { humic acids }\end{array}$ & $21-26$ & $3930 \pm 90$ & $2580-2290 \mathrm{cal} \mathrm{BC}$ & $2900-2100$ cal BC \\
\hline $\begin{array}{l}\text { WL2 } \\
3\end{array}$ & Le-6501 & $\begin{array}{l}\text { Total } \\
\text { humic acids }\end{array}$ & $36-41$ & $5840 \pm 50$ & $4790-4670 \mathrm{cal} \mathrm{BC}$ & $4850-4580$ cal BC \\
\hline $\begin{array}{l}\text { WL2 } \\
4\end{array}$ & Le-6502 & $\begin{array}{l}\text { Hot } \\
\text { humic acids }\end{array}$ & $41-44$ & $4670 \pm 400$ & $3900-2900 \mathrm{cal} \mathrm{BC}$ & - \\
\hline $\begin{array}{l}\text { WL2 } \\
5\end{array}$ & Le-6503 & $\begin{array}{l}\text { Hot } \\
\text { humic acids }\end{array}$ & $44-49$ & $6530 \pm 400$ & $5800-5000$ cal BC & - \\
\hline $\begin{array}{l}\text { WL2 } \\
6^{\mathrm{a}}\end{array}$ & Le-6623 & $\begin{array}{l}\text { Total } \\
\text { humic acids }\end{array}$ & $22-35$ & $2460 \pm 120$ & $770-480 \mathrm{cal} \mathrm{BC}$ & $850-200 \mathrm{cal} \mathrm{BC}$ \\
\hline $\begin{array}{l}\text { WL2 } \\
7^{\mathrm{a}}\end{array}$ & Le-6624 & $\begin{array}{l}\text { Total } \\
\text { humic acids }\end{array}$ & $35-50$ & $4360 \pm 150$ & $3650-3100$ cal BC & $3700-2900 \mathrm{cal} \mathrm{BC}$ \\
\hline
\end{tabular}

a Samples collected in 2002.

For WL-2, only ${ }^{14} \mathrm{C}$ dates for the deposits between 20 and $50 \mathrm{~cm}$ depth could be obtained. The lower layers did not contain sufficient organic material for dating. One ${ }^{14} \mathrm{C}$ date could be produced for WL-1 for the layer of 20-40 cm (2090 \pm 100 BP; Le-6195). During the 2001 season, we collected a small number of samples using both a Dakhnovsky and a Russian corer. The deposits had a low organic content, resulting in larger measurement errors in the liquid scintillation analysis. In 2002, we opened another trench at White Lake to collect additional samples with sufficient material for dating. The layer at $22-35 \mathrm{~cm}$, corresponding to the Scythian period, was dated $2460 \pm 120 \mathrm{BP}$ (Le6623). A deeper layer, corresponding to the Middle Bronze Age, was dated $4360 \pm 50 \mathrm{BP}$ (Le-6624).

Of the 33 samples in the White Lake-2 (WL-2) core, only 19 samples contained enough pollen for percentage calculations. The total length of this core was $130 \mathrm{~cm}$, but most samples from the lowest $25 \mathrm{~cm}$ did not contain pollen. The pollen and microfossil diagram is shown in Figure 5. The following zones are distinguished in the diagram:

- Zone WL-I (105-60 cm). From the base of the core, Artemisia pollen are dominating and reach the highest value of the whole record (around 70\%), while Chenopodiaceae, Poaceae, and Ephedra are present permanently as minor components. Tree-pollen percentages are very low 


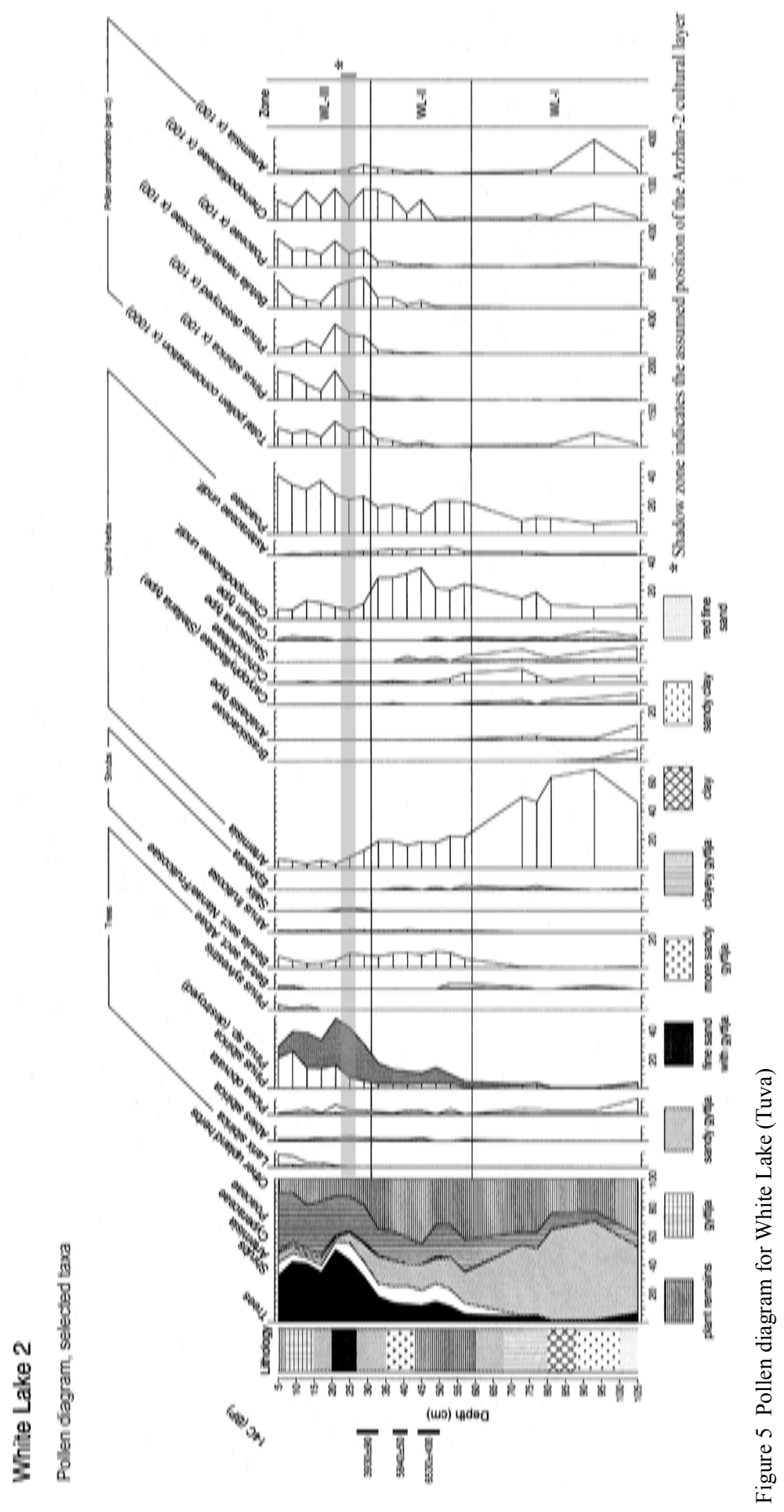


and constant. The pollen concentrations are extremely low, except for the only sample at the basal part of zone. All these features suggest low local and regional pollen production, a persistence of stony steppe within the valley, and scarce forest or even tree-less conditions in the mountains during a relatively dry and cold climate.

- Zone WL-II (60-32 cm; $6530 \pm 400$ BP [Le-6503] in the middle of zone, $5840 \pm 50$ BP [Le6501], upper part of the zone). The Chenopodiaceae frequency increases to $37 \%$, and dominates over Artemisia and Poaceae at the second half of zone, indicating that desert and semidesert conditions persisted in the depression, and/or that halophytic vegetation was present in the lake area. This suggests lower moisture, i.e., there is more evaporation than precipitation. Low pollen concentrations, a sign of low biomass production during this period, also indicate arid conditions. A gradual increase of pine pollen, taken together with the appearance of shrub birch pollen, suggests the establishment of forest and shrub belts in the mountains. These phenomena are all indications of dry and warm climate conditions during this period.

- Zone WL-III (32-5 cm; $3930 \pm 90$ BP [Le-6499], beginning of the zone). The most remarkable feature of this zone is a sudden rise of tree-pollen values to $54 \%$, together with a sharp increase of the total pollen concentration. Xerophitic taxa, Artemisia and Chenopodiaceae, decline to $3 \%$ and 7\%, respectively; Ephedra disappears completely, while Poaceae pollen gradually increase towards the top of core, reaching their highest value of $41 \%$. Cyperaceae become more frequent, indicating its settlement in the local wetlands. Both grasses and sedges start to colonize the lake shores and replace halophytic wetland plant communities. This reflects a significant vegetation shift from semi-desert to herbaceous steppe in the valley, and a relatively rapid spreading of mountain forest; this also indicates the onset of more humid conditions. The highest concentration of shrub birch pollen suggests a relatively cold climate at the transition between dry and wet periods.

Three groups of elements are found in the deposits of WL-2: (1) a detrital (alumosilicate) element group, consisting of $\mathrm{K}, \mathrm{Al}, \mathrm{Ti}, \mathrm{Ba}, \mathrm{Fe}$; (2) $\mathrm{Sr}, \mathrm{Ca}, \mathrm{S}, \mathrm{CO}_{2}, \mathrm{~N}, \mathrm{C}_{\text {org }}$; and (3) an organic group consisting of carbonates, sulfates, and organic complexes. Since all $\mathrm{CO}_{2}$ is bound to $\mathrm{Ca}$ in carbonate, the calcium excess combined with strontium constitutes sulfate complexes. Natrium shows minor correlation with all elements; Na probably combines into halogen minerals. Our analysis also shows that there is no correlation between alumosilicate elements and elements included in organic material, indicating relative temperature variations. Increasing salinity $(\mathrm{Na})$ of the lake reflects a dry environment, indicating humidity changes.

The results of the climatic reconstructions based on geochemistry are shown in Figure 6. The following major fluctuations are observed:

1. The period when the lower layers $(135-95 \mathrm{~cm})$ were deposited was characterized by a cool, dry climate, and (based on the data of the granulometric analysis) the depth of the lake basin was rather low.

2. During the next period $(95-58 \mathrm{~cm})$, the climate was even cooler, but the lake level was relatively high. The higher concentration of $\mathrm{N}$ and $\mathrm{Mn}$ indicates oxidation processes in the lake.

3. During the following period $(57-30 \mathrm{~cm})$, one can observe a temperature rise and relatively dry conditions (shallow lake).

4. Maximal dry conditions occurred around 3900 BP $(33-30 \mathrm{~cm})$.

5. During the youngest period $(30-15 \mathrm{~cm})$, beginning around $3000-2500 \mathrm{BP}$, more wet conditions and higher temperatures prevailed. Local organic production was high, leading to terrestrialization of the lake at the sampling site. 


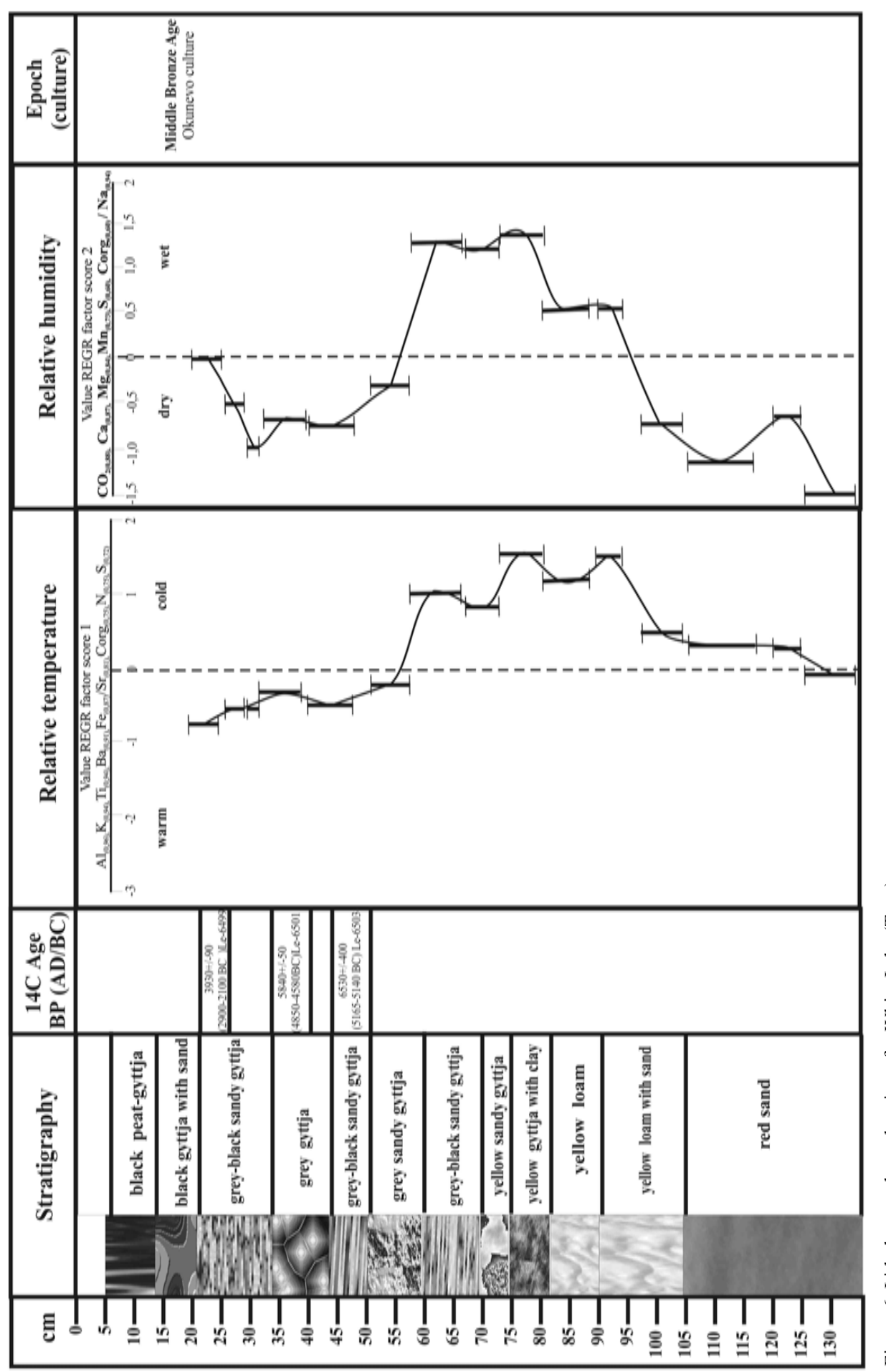

蛋 
The famous Arzhan-2 Scythian monument $\left(52^{\circ} 03^{\prime} \mathrm{N} ; 93^{\circ} 35^{\prime} \mathrm{E}\right)$ is located about $1 \mathrm{~km}$ from the White Lakes. This monument was discovered in 2001 (Chugunov et al., forthcoming). The first chronological study is presented in these proceedings (Zaitseva et al., these proceedings). This monument is dated to the 7th century BC. The ${ }^{14} \mathrm{C}$ dates of the deposits from the Arzhan- 2 monument are in Table 3.

Table 3 The ${ }^{14} \mathrm{C}$ results for the deposits from Arzhan-2 monument.

\begin{tabular}{lllllcc}
\hline & & & & & \multicolumn{2}{c}{ Calibrated dates, cal BC } \\
\cline { 6 - 7 } $\mathrm{Nr}$ & Lab nr & Material & Location & ${ }^{14} \mathrm{C}$ age (BP) & $1 \sigma$ & $2 \sigma$ \\
\hline 1 & Le-6219 & charcoal & $\begin{array}{l}\text { Outside the } \\
\text { royal grave 5 }\end{array}$ & $3000 \pm 20$ & $1300-1130$ & $1370-1120$ \\
2 & GrA-18938 & $\begin{array}{l}\text { Total humic } \\
\text { acids from soil }\end{array}$ & $\begin{array}{l}\text { Inside the } \\
\text { royal grave 5 }\end{array}$ & $2530 \pm 70$ & $800-520$ & $810-410$ \\
\hline
\end{tabular}

Unfortunately, during the monument construction, the soil layers were disturbed. Based on archaeological evidence, it was suggested that this location was occupied by people of the Okunevo culture before the burial mound was built. $\mathrm{A}{ }^{14} \mathrm{C}$ date of charcoal from a pit fill (3000 $\pm 20 \mathrm{BP}$, Le-6219) supports this hypothesis. Several profiles were sampled during the excavation of the barrow; a pollen diagram was produced (Figure 7) and samples were analyzed geochemically (Figure 8).

The pollen diagram is composed of 4 sets of samples representing stratigraphical levels:

1. A buried cultural level (1 sample) belonging to the Okunevo culture dated to $3000 \pm 20 \mathrm{BP}$ (Le6219);

2. The bottom of buried soil below the Arzhan-2 monument;

3. The surface of buried soil directly connected with the Arzhan-2 barrow construction, dated to $2530 \pm 70$ BP (GrA-18938);

4. The modern surface.

The low temporal resolution of the WL-2 sediment core did not allow us to make a direct correlation between the WL-2 pollen record (Figure 5) and pollen data from the Arzhan-2 monument (Figure 7). To determine a possible stratigraphical position of the main cultural layer of Arzhan-2 within the WL-2 pollen record, we used the changes in tree-pollen curves. These long-distance transported taxa have a regional significance, while the values of non-arboreal taxa are more variable and dependent on the local environments. According to the Arzhan-2 pollen data, the total tree-pollen sum from the surface of the buried soil is higher than that from the Okunevo cultural level and lower than that from the modern surface. Based on these data, we suppose that the Scythian cultural layer corresponds stratigraphically to the lower part of the WL-III zone in the WL-2 pollen diagram.

Based on these paleoenvironmental data, it is possible to connect the development of archaeological culture with the climatic changes. It is clear that the Arzhan-2 monument was erected during a period of relatively wet and warm climatic conditions.

\section{DISCUSSION}

\section{Cultural Developments in the Minusinsk Valley}

We compared our detailed paleoclimatic data with the occupation records of ancient cultures to determine possible relationships. After more than $200 \mathrm{yr}$ of archaeological research in the Minusinsk basin, much is known about the sequence of cultures (Vadeckaya 1986; Vasiliev 2001). 

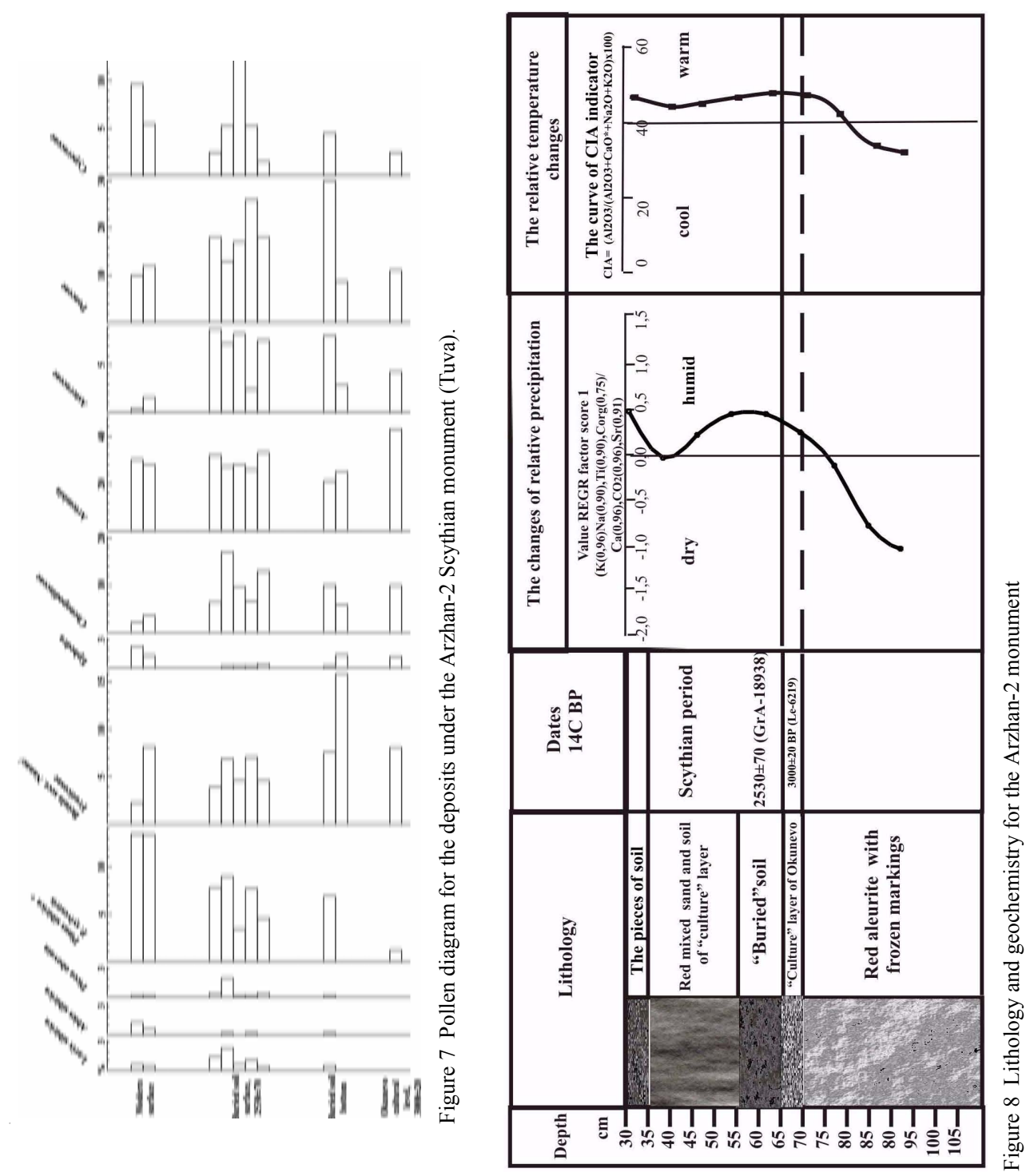
The steppe areas in Khakasia were occupied only since the end of the Neolithic period, (Lisytsin 1988). The first Bronze Age cultures found in this territory, the Afanasievo, dated to 4th-3rd millennium BC, and the Okunevo, dated to the end of the 3rd millennium BC (Görsdorf et al. 1998, 2001), have no local origin. They could have come from the Black Sea region, from the southern Caspian territory, or from Central Asia. The Middle Bronze Age of the northern part of the Minusinsk valley is characterized by the Andronovo culture, dated to the 18th-14th century BC (Görsdorf et al. 1998).

The archaeological data do not reveal why the Andronovo population did not move to the southern part of the Minusinsk valley; it is possible that environmental conditions were a limiting factor. At the end of the 2nd millennium BC, the climate in the Minusinsk valley was relatively dry and cool. The best represented Late Bronze Age culture in the Minusinsk valley is the Karasuk culture, dated to the 14th-10th century BC (Görsdorf et al. 1998, 2001; Bokovenko 1995; Bokovenko and Legrand 2000). Thousands of burial mounds and settlements of this culture were discovered in the steppe zone of the Yenisei River valley. Artifacts of this culture were found in a large region, ranging from central Kazakhstan to Mongolia and China (Novgorodova 1970; Chlenova 1972). The archaeological materials show that in this period horse-riding became important and that the transition to a nomadic stock-breeding economy took place.

The Karasuk culture developed into the early Iron Age Tagar culture (1st millennium BC; Vadeckaya 1986), which is contemporary and closely related to Scythian cultural groups in other parts of the Eurasian steppe belt. The change from the latest phase of the Late Bronze Age to the beginning of the Iron Age, when the Tagar culture began to develop, does not show a break in the cultural development. The earlier stage of the Scythian epoch (the Tagar culture) is dated to the 8th-9th century BC (Sementsov et al. 1997; Alekseev et al. 2001). We note that the evidence for climate change at the Subboreal-Subatlantic transition is also dated to the 9th century BC (van Geel et al. 1996, 1998). In the Kutuzhekovo lake deposits, the dates of $2985 \pm 40$ BP (GrA-20687) and $2630 \pm 180$ BP (Le-6232) mark the transition to wetter climatic conditions. However, in the region to the north of the Sayan Mountains, there is no evidence pointing to causal relationships between climate change and cultural developments.

\section{Cultural Development in the Uyuk Valley}

There are considerable differences in cultural development for the regions of the Minusinsk and Uyuk valleys, even though they are relatively close to each other. In Tuva, only a few Neolithic sites were found in the Sayan Canyon of the Yenisey River (Toora-Dash and Ust'-Khemchik III). The multi-layered Toora-Dash site is well stratified, showing the cultural development from the late Neolithic up to the Bronze and Iron Ages (Semenov 1992, 2003). According to archaeological data, some occupation of the Tuvinian steppe started during the second half of the 2nd millennium BC, when the pastoral stock-breeding population appeared (the Okunevo culture). This culture existed to the time of the Scythian cultures, which began to occupy this territory during the 1st millennium BC.

The almost complete lack of Bronze Age archaeological records is remarkable. The situation changed completely after the 9th century BC, when the Scythian culture emerged in Tuva, much earlier than in the western parts of the Eurasian steppe zone. The great Arzhan-1 barrow, excavated by the famous Russian archaeologist M Gryaznov, yielded very early Scythian material dated to the late 9th-early 8th century BC (Gryaznov 1980; Gryaznov 1984). This early date is confirmed by the ${ }^{14} \mathrm{C}$ dates as well as by archaeological arguments, because certain types of horse bridles from the central grave can be connected with the pre-Scythian phase in the Black Sea region. 


\section{Climate Changes}

The reconstruction of the climate change can be compared with the cultural development in both the Minusinsk and the Uyuk valleys. Despite some similarities, there are major differences in the occupation of both territories. Practically no Mesolithic and Neolithic cultures (10,000-5000 BP) are known in both areas. This is difficult to explain here, because only 2 cores of lake deposits were studied which mainly represent the Late Holocene. Some early nomads appeared in both territories during the Bronze Age. In the Minusinsk valley, early Bronze Age occupation (Aphanasievo culture) was quite intense. However, in the Uyuk valley (Tuva), only a few traces of the Middle Bronze Age Okunevo culture were recorded. The most intensive occupation of both territories occurred in the beginning of the 1st millennium BC, when the more impressive Scythian time cultures started to exist (Tagar culture in the Minusinsk valley and Aldy-Bel culture in the Uyuk valley). The comparison between archaeological material available and the paleoenvironmental data yields important information about the influence of climate change.

The relatively thick deposits from Kutuzhekovo Lake (Minusinsk valley) have a better time-resolution than the record from White Lake. Unfortunately, in both cases, the lower parts of the core did not contain enough organic matter for ${ }^{14} \mathrm{C}$ dating. But it is evident that in both cases more humid conditions started during the Middle Bronze Age and culminated during the early Iron Age (shown by increased local and regional biomass production). The major change occurred between 2700 and 2500 BP (Figures 3, 5: zone boundaries KTH-I/II and WL-II/III). The pollen, sedimentological, and geochemical records all show that the climate suddenly became more humid than during the preceding period. Humidity is a major factor influencing the plant biomass production of the steppe. This may well be the reason that in first instance the steppe of the Minusinsk valley was more densely occupied by nomadic tribes than the Uyuk valley. In the Uyuk valley, the conditions for biomass production were less good, taking into account the more continental climate and lower precipitation, than in the Minusinsk valley. According to our data, the forests have never covered the Uyuk valley during the Holocene, while today forest-steppe areas occur in the Minusinsk valley.

Only in the early part of the 1st millennium BC did the climatic conditions in the Uyuk valley improve sufficiently so that the occupation capacity was high enough for a dense human population. The Arzhan-1 barrow located in this region was constructed during the 9th century BC, while the Arzhan-2 monument dated to the 7th century BC. We suppose that a climatic factor played a major role in the settlement history of Tuva (van Geel et al., forthcoming). Prehistoric communities living in marginal areas (in terms of climatic conditions and related with food production) may react in a very sensitive way to environmental changes, because such changes can have an enormous impact on their way of life and even survival.

\section{CONCLUSION}

The main occupation of the Minusinsk valley (Krasnoyarsk district) and the Uyuk valley (Tuva) started during the Bronze Age, when the humidity of the steppe areas was increasing. Based on the available record, we conclude that the Minusinsk valley was at first more attractive than the southern, too-dry Uyuk valley. Increased humidity and related biomass production and carrying capacity were the main factors influencing the start of the early Iron Age occupation of the Uyuk valley in Tuva.

\section{ACKNOWLEDGEMENTS}

This research was supported by the Russian Humanitarian Foundation (03-01-00099a) and the Dutch-Russian Scientific Cooperation Program of the Netherlands Organisation for Scientific Research (NWO grant 047.009.005). 


\section{REFERENCES}

Alekseev AY, Bokovenko NA, Boltrik Y, Chugunov KA, Cook G, Dergachev VA, Kovalyukh N, Possnert G, van der Plicht J, Scott EM, Sementsov A, Skripkin V, Vasiliev S, Zaitseva G. 2001. A chronology of the Scythian antiquities of Eurasia based on new archaeological and ${ }^{14} \mathrm{C}$ data. Radiocarbon 43(2B):1085-107.

Arslanov KhA. 1987. Radiocarbon: Geochemistry and Geochronology [translated from Russian]. Leningrad: University Press. 296 p.

Bokovenko NA. 1995. The Tagar culture in the Minusinsk basin. In: Davis-Kimball J, Bashilov VA, Yablonskiy LT, editors. Nomads of the Eurasian Steppes in the Early Iron Age. Berkeley, California: Zinat Press. p 296-314.

Bokovenko NA, Legrand S. 2000. Das karasukzeitliche Gräberfeld Anchil Chon in Chakassien. Eurasia Antiqua 6:209-48.

Bor-ming J, Sylvain G, Jiamao H. 2001. Geochemistry of the Xining Jixian sections, loess plateau of China: eolian dust provenance and paleosol evolution during the last $140 \mathrm{ka}$. Chemical Geology 178:71-94.

Chen J, Zhisheng A, Head J. 1999. Variation of Rb/Sr ration in the loess-paleosol sequences of central China during the last 130,000 years and their implications for monsoon paleoclimatology. Quaternary Research 51: 215-9.

Chichagova OA. 1985. Radiocarbon Dating of Numinic Acids from Solid. Gerasimov IP, editor. Moscow: Nauka Press. 272 p. In Russian.

Chlenova NL. 1972. The chronology of the monuments belong to the Karasuk epoch [translated from Russian]. Moscow: Nauka press. The Materials and Investigations on Archaeology of the Institute of Archaeology (182):248.

Chugunov KV, Dergachev VA, Nagler A, Parzinger G, Possnert G, Sementsov AA, Scott EM, van Geel B, van der Plicht J, Vasiliev SS, Zaitseva GI. Forthcoming. First data on the chronological study of the unique Tsar burial mound Arzhan-2 in Central Asia (Tuva Republic). 4th International Symposium on ${ }^{14} \mathrm{C}$ and $\mathrm{Ar}$ chaeology. Oxford, 2002.

Dergachev VA, Vasiliev SS, Sementsov AA, Zaitseva GI, Chugunov KA, Slusarenko IJ. 2001. Dendrochronology and radiocarbon dating methods in archaeological studies of Scythian sites. Radiocarbon 43(2A):41724.

Efimtsev EA. 1957. Environments of Tuva In: Klimenko P, editor. Climate Review [translated from Russian]. Moscow: Nauka Press. p 46-65.

Eusterhaues K, Lechterbreck J, Shneider J, Wolf-Brozio U. 2002. Late- and post-glacial evolution of Lake Steisslingen (I). Sedimentary history, palynological record and inorganic geochemical indicators. Palaeogeography, Palaeoclimatology, Palaeoecology 187: $341-71$.

Faegri K, Iversen J. 1989. Textbook of Pollen Analysis.
Fourth Edition. New York: John Wiley \& Sons. 328 p. Gavlina GB. 1954. The climate of Khakasia. Natural Environment and Agriculture of the Khakassia Republic [translated from Russian]. Moscow: Nauka Press. p 14-42.

Goldberg L, Fedorin MA, Grachev MA, Bobrov VA. 2000. Periodic signals of orbital forcing during Brunes in geochemical records of Baikal Lake deposits. In: The Problems of Climatic and Environmental Reconstructions of Holocene and Pleistocene [translated from Russian] 2:121-31.

Görsdorf J, Parzinger H, Nagler A, Leontev N. 1998. Neue ${ }^{14} \mathrm{C}$-Datierungen für die Sibirische Steppe und ihre Konsequenzen für die regionale Bronzezeitchronologie. Eurasia Antiqua 4:73-80.

Görsdorf J, Parzinger H, Nagler A. 2001. New radiocarbon dates of the north Asian steppe zone and its consequences for the chronology. Radiocarbon 43(2B): 1115-20.

Gracheva R. 2002. Abrupt environmental change and depopulation of Upper Volga lowland, central Russia, around 2600 BP. Abstracts "Environmental Catastrophes and Recoveries in the Holocene" Conference. Brunel University, UK. (http://atlas-conferences.com/ cgi-bin/abstract/caiq-71).

Grunert J, Lehmkuhl F, Walther M. 2000. Paleoclimatic evolution of the Uvs Nuur basin and adjacent areas (western Mongolia). Quaternary International 65/66: 171-92.

Gryaznov MP. 1980. Arzhan-The Tsar barrow of the Early Scythian Time [translated from Russian]. Leningrad: Nauka Press. 62 p.

Gryaznov MP. 1984. Der Großkurgan von Arzhan in Tuva, Südsibirien. Materialien zur Allgemeinen und Vergleichenden Archäologie 23. München: Verlag C.H. Beck.

Haasan FA. 1985. Fluvala system and geoarchaeology in arid lands: with examples from North Africa, Near East, and the American Southwest. In: Stein JK, Farrand WR, editors. Archaeological Sediments in Context. Peopling of the Americans Edited Volume Series: Volume 1. Orono, Maine: Center for Study of Early Man Institute for Quaternary Studies, University of Maine. p 53-68.

Lehmkuhl F, Schlütz F, Beckert C, Klinge M. 1998. Zur Jungpleistozänen und Holozänen Klimageschichte des Turgen-Charichira, Mongolischer Altai. Jenaer Geographische Manuskripte 19:43-4.

Lisitsyn NF. 1988. To the question about the Neolithic in Khakasia [translated from Russian]. Short Reports of the Institute of Archaeology (KSIA) 193:15-20.

Novgorodova EA. 1970. Central Asia and the Karasuk Problem. Moscow: Nauka Press. 192 p. In Russian.

Peck JA, Khosbayar P, Fowell SJ, Pearce RB, Ariunbileg S, Hansen BCS, Soninkhishig N. 2002. Mid to Late Holocene climate change in north central Mongolia as 
recorded in the sediments of Lake Telmen. Palaeogeography, Palaeoclimatology, Palaeoecology 183: 135-53.

Semenov VA. 1992. The Neolithic and the Bronze Age in Tuva. Saint Petersburg: IHMC Press. 152 p. In Russian.

Semenov VA. 2003. The Neolithization of the Minusinsk valley and Tuva (The Upper Yenisey Neolithic culture) [translated from Russian]. In: Timofeev V, Zaitseva G, editors. The Chronology and the Interaction of the Neolithization of Eurasia. Saint Petersburg: IHMC press. p 212-6.

Sementsov AA, Zaitseva GI, Gorsdorf J, Bokovenko NA, Parzinger G, Nagler A, Chugunov KV, Lebedeva LM. 1997. The chronological questions of the Scythian nomads for the southern Siberia and Central Asia regions [translated from Russian]. Radiocarbon and Archaeology 2:86-94.

Soltanpour PN, Johnson GW, Workman SM, Benton JS, Miller RJO. 1996. Inductively coupled plasma emission spectrometry and inductively coupled plasmamass spectrometry. In: Methods of Soil Analysis. Madison, Wisconsin, USA: Soil Science Society of America, Inc.; American Society of Agronomy, Inc. p 91135.

Speranza A, van Geel B, van der Plicht J. 2002. Evidence for solar forcing of climate change at ca. $850 \mathrm{cal} \mathrm{BC}$ from a Czech peat sequence. Global and Planetary Change 35:51-65.

Vadeckaya EB. 1986. The Archaeological Sites in the Steppe Zone of the Middle Yenisy River Basin [translated from Russian]. Leningrad: Nauka Press. 179 p.

van Campo E, Gasse F. 1993. Pollen- and diatom-inferred climatic and hydrological changes in Sumxi Co basin (western Tibet) since 13,000 yr BP. Quaternary Research 39:300-13.

van der Plicht J, Aerts A, Wijma S, Zondervan A. 1995. First results from the Groningen AMS facility. Radiocarbon 37(2):657-61.

van der Plicht J, Wijma S, Aerts AT, Pertuisot MH,
Meijer HAJ. 2000. The Groningen AMS Facility: status report. Nuclear Instruments and Methods in Physics Research B 172:58-65.

van Geel B, Buurman J, Waterbolk HT. 1996. Archeological and paleoecological indications for an abrupt climate change in the Netherlands and evidence for climatological teleconnections around 2650 BP. Journal of Quaternary Science 11:451-60.

van Geel B, van der Plicht J, Kilian MR, Klaver ER, Kouwenberg JHM, Renssen H, Reynaud-Farrera I, Waterbolk HT. 1998. The sharp rise of $\Delta^{14} \mathrm{C}$ ca. $800 \mathrm{cal} \mathrm{BC}$ : possible causes, related climatic teleconnections and the impact on human environments. Radiocarbon 40(1):535-50.

van Geel B, Zaitseva GI, Bokovenko AN, Chugunov KV, Dergachev KV, Dirksen VG, Koulkova MA, Nagler A, Parzinger G, van der Plicht J, Bourova ND, Lebedeva LM. Forthcoming. Chronology and possible links between climatic and cultural change during the first millenium BC in southern Siberia and Central Asia. Journal of Archaeological Sciences.

Vasiliev SA. 2001. The later complexes of the multilayer site Uy-II and the problem of the development of the Stone Age cultures in the Upper Yenisey River Basin during the Holocene. St. Petersburg: Archaeological News 8:62-76. In Russian.

Vasiliev SS, Dergachev VA. 2002. The $\sim 2400$-year cycle in atmospheric radiocarbon concentration: bispectrum of ${ }^{14} \mathrm{C}$ data over the last 8000 years. Annales Geophysicae 20:115-20.

Zaitseva GI, Chugunov KV, Dergachev VA, Nagler G, Parzinger G, Scott EM, Sementsov AA, Vasiliev S, van Geel B, van der Plicht J, Lebedeva LM. 2004. Chronological studies of the Arzhan-2 Scythian monument in Tuva. Radiocarbon, these proceedings.

Zaitseva GI, Timofeev VI, Sementsov AA. 1999. C14 dating in the Institute for the History of Material Culture of Russian Academy of Sciences: history, status of work, results and prospects. Russian Archaeology 3:5-22. In Russian. 